\title{
Hematological and antioxidants responses of dairy cow fed with a combination of feed and duckweed (Lemna minor) as a mixture for improving milk biosynthesis
}

\author{
UJANG HIDAYAT TANUWIRIA ${ }^{1, \boldsymbol{v}}$, ANDI MUSHAWWIR ${ }^{2}$ \\ ${ }^{1}$ Laboratory of Ruminant and Feed Chemistry, Department of Animal Nutrition and Feed Technology, Faculty of Animal Sciences, Universitas \\ Padjadjaran. Jl. Raya Bandung-Sumedang Km. 21, Jatinangor, Sumedang 45363, West Java, Indonesia. Tel.: +62-22-7798241, Fax.: +62-22-7798212, \\ vemail: hidayat.tanuwiria@gmail.com \\ ${ }^{2}$ Laboratory of Animal Physiology and Biochemistry, Department of Animal Nutrition and Feed Technology, Faculty of Animal Sciences, Universitas \\ Padjadjaran. Jl. Raya Bandung-Sumedang Km. 21, Jatinangor, Sumedang 45363, West Java, Indonesia
}

Manuscript received: 23 July 2020. Revision accepted: 23 September 2020.

\begin{abstract}
Tanuwiria UH, Mushawwir A. 2020. Hematological and antioxidants responses of dairy cows fed with a combination of feed and duckweed (Lemna minor) as a mixture for improving performance. Biodiversitas 21: 4741-4746. A total of twenty-five, 5-7 ${ }^{\text {th }}$ lactation-old or $7-8^{\text {th }}$ years-old dairy cows were used in the current study to study the effect of feed duckweed (Lemna minor) on the hematological status and parameters related antioxidant in the dairy cow. Each group of treatment involved 5 replicates with a dairy cow each (5 dairy cows per group). All of the group was provided ration following F0 = Uncultivated grass (UG) 60\% and supplemented concentrated (C) 40\%; F1 = UG 50\%+fresh duckweed 10\%+C 40\%; F2 = UG 60\%+fresh duckweed 3\%+C 37\%; F3 = UG 50\%+fresh duckweed 10\%+dried duckweed 3\%+C 37\%; F4 = UG 45\%+fresh duckweed 15\%+dried duckweed 2\%+C 38\%. Blood samples were collected from each dairy cow monthly beginning at the first month of this experiment, from the tail vein (vena coccygeal), using a sterilized syringe and vacuum tube containing $\mathrm{K}_{3}$ EDTA. Hematological parameters were analyzed by a hematology analyzer. The blood samples collected were also centrifuged to separate the plasma. The plasma was used to determine of concentration of parameters related to antioxidant by an automatic biochemical analyzer, using a commercial kit. All procedure of the analysis was following based on the Biolabo kit (Franch) and Randox kit (UK). Based on in this current study showed that increased hematological condition and antioxidants profile in dairy cow supplemented duckweed. Supplemented duckweed can be improved physiological condition (hematologic and antioxidants) in the dairy cow.
\end{abstract}

Keywords: Antioxidant, duckweed, dairy cow, Lemna minor, hematologic

\section{INTRODUCTION}

Dairy cows need an ideal housing environment, to be able to produce optimally. Dairy farming systems in West Java and generally in Indonesia, have not shown a good maintenance system. This condition causes high $\mathrm{NH}_{3}$ levels in the housing, pathogenic microbes infection, low milk production. $\mathrm{NH}_{3}$ levels of the cage also cause responses to olfactory receptors. On the other hand, the use of alternative feeds needs to be encouraged to reduce feed costs, and at the same time improve the performance of dairy cattle.

Application of natural matter as feed mixes has been reported in animals. The potential use of duckweed (Lemna minor) feed ingredients is supported by the high protein content which ranges from $22.40 \%$, crude fiber $10.16 \%$ (Sasmaz et al. 2015), and its metabolic energy reaches 2342 kcal.kg-1 dry matter, amino acids especially lysine reached $6.9 \mathrm{~g}$ in $100 \mathrm{~g}$, methionine $1.4 \%$, and histidine $2.7 \%$ (Tanuwiria et al. 2011), and rich in minerals and vitamin A (Saygideger et al. 2015), also amino acid microminerals (Sazmaz et al. 2015).

The productivity of duckweed is high, ie every two days biomass is produced once as initial biomass, if regulated effectively it can produce 10-30 tons of dry matter.ha ${ }^{-1}$.year ${ }^{-1}$ with a content of $43 \%$ crude protein
(Sasmaz et al. 2015; Lai et al. 2016). The results of the study by Ippolito et al (2014) showed that the productivity of duckweed biomass was about $176.38 \mathrm{~g} / \mathrm{m}^{2}$ in wet conditions or 6.24 g. $\mathrm{m}^{2}$ in dry conditions, whereas the results of studies in the Cikajang Garut area, the productivity of duckweed around $234.37 \mathrm{~g} . \mathrm{m}^{2}$ in a wet state (Tanuwiria et al. 2011). Based on the high protein content, duckweed has potential as a feed ingredient. The duckweed biomass can be used as a food source of protein reserves for livestock. Each species of Lemna sp. has a variety of nutritional and anti-nutritional contents and is largely determined by the growth in vitro (Pearce et al. 2013; Geburt et al. 2015).

The blood (extracellular fluid) functions as the transport carbon dioxide, oxygen, carrier of nutrient, metabolic waste, and the pathway of humoral transmission. So the blood (hematological and biochemical parameters) would consider the physiological state of the animal body. Therefore, the current experiment was to evaluate potential Many reports have shown that duckweed found a significant effect in animals; species such as laying hen, broiler, ruminant. However, only limited published and information is available about dietary duckweed for the dairy cow as we know. Therefore, the current experiment was to evaluate the supplementation of duckweed as a 
ration to hematology of dairy cows and its potential as an antioxidant.

\section{MATERIALS AND METHODS}

\section{Study area}

The research was located in Cikajang, Garut District, West Java, Indonesia. This area has a very strategic potential. Several supporting reasons, namely the farmers in Cikajang have been raising dairy cattle for a long time, with a population of 1755 . Besides that, the dairy farms in this area have been managed with good management under the dairy farmer cooperation.

\section{Experimental design}

\section{Animal samples and treatment}

The protocol of this experiment and the animal samples were approved and handled in accordance with good animal practice, also the authors have declared that this study no competing interest exists. A total of twenty-five, 5- $7^{\text {th }}$-lactation-old dairy cows were used in the current study. The cow samples were obtained from a local breeding farm company. The dairy cow was individually ear-banded. The samples were placed onto individual housing, measuring $140 \times 230 \mathrm{~cm}$ in an environmentally controlled house for six months.

The housing temperature was exposed neutral temperature zone for a dairy cow, i.e. $18-25^{\circ} \mathrm{C}$ during the experimental period, and the relative humidity was maintained between 65 and $85 \%$. Fed and water were presented for ad libitum consumption. The animal samples were randomly allocated to 5 treatment groups (a group as the control (without duckweed) and the other group as a treatment group of duckweed).

Each group of treatment involved 5 replicates with a dairy cow each (5 dairy cows per group). All of the group was provided ration following: (i) $\mathrm{F} 0=$ Control group, Uncultivated grass (UG) $60 \%$ and supplemented concentrated (C) $40 \%$, (ii) F1 = UG 50\%+fresh duckweed $10 \%+\mathrm{C} 40 \%$, (iii) $\mathrm{F} 2=\mathrm{UG} 60 \%+$ fresh duckweed $3 \%+\mathrm{C}$ $37 \%$, (iv) $\mathrm{F} 3=\mathrm{UG} 50 \%+$ fresh duckweed $10 \%+$ dried duckweed $3 \%+\mathrm{C} 37 \%$, (v) F4 = UG 45\%+fresh duckweed $15 \%+$ dried duckweed $2 \%+\mathrm{C} 38 \%$.

Uncultivated grasses were used in this study consist of Paspalum conjugatum and Cynodon dactylon, while the concentrate composition used consists of tofu dregs, rice bran, soybean dregs.

\section{Sample collection and analysis}

Blood samples were collected from each dairy cow monthly in beginning in the first month of this experiment, for six months. The blood samples were sucked from the tail vein (vena coccygeal), using a sterilized syringe and vacuum tube containing $\mathrm{K}_{3}$ EDTA. Hematological parameters were analyzed by a Mindray Auto Hematology Analyzer, BC-5300. The EDTA tubes containing blood samples were placed under a suction needle, then $100 \mu \mathrm{L}$ blood samples were automatically filled with a hematology analyzer.

The blood sample collected was also centrifuged to separate the plasma. The plasma was used to determine of concentration of parameters related to antioxidant by an automatic biochemical analyzer from Biolabo with a model of Kenza 240TX , using a commercial kit. All procedure of the analysis was following based on the Biolabo kit (Franch) and Randox kit (UK).

\section{Data analysis}

The data were statistically analyzed by one-way analysis of variance (ANOVA) using the completely randomized design procedure, with software of SAS Version 8.216 for a completely randomized design. Blood parameters and antioxidant levels were subjected to analysis of variance. The difference between the means of all treatments was separated by Duncan's multiple range tests (SAS Institute 2001) at a 95\% significant level or $\alpha=$ $5 \%$. Each mean level of hematology and antioxidants, followed by the standard deviation $( \pm \mathrm{SD})$.

\section{RESULTS AND DISCUSSION}

\section{Hematological responses}

The effects of duckweed supplementation with different levels on the hematologic profile of dairy cows are shown in Table 1. Diet supplemented with duckweed, individually or combination of concentrate with duckweed had significant effect $(\mathrm{P}<0.05)$ on all of the hematological parameters. Based on the results of the present study (Table 1), overall, it showed that the addition of duckweed in the dairy cattle rations can improve the hematological condition of dairy cows. The improvement in hematologic levels with duckweed administration can be explained as the impact of duckweed bioactive content increases the rate of erythropoiesis and prevents damage to blood cells, and also decreases the risk of oxidative stress.

The effects of duckweed supplementation with different levels on the hematologic condition of the dairy cow are shown in Table 1. Diet supplemented with duckweed, individually (only fresh duckweed) or combination of fresh with dried of duckweed had a significant effect, such as RBC value in the dairy group of F4 ration was higher (5.24, $\mathrm{P}<0.05)$ than dairy group of $\mathrm{F} 1$ ration was 4.78 , and similar results showed on all of the hematological parameters. The results of the current study showed that a combination of duckweed can be improving blood values. Some studies have reported and suggested that natural substances significantly increased hematological values. This is in accordance with Odore et al. (2011) who reported that natural extract increased the differential leukocytes count. The use of natural substances on hematological status also have reported by Siskos et al. (2017), which showed a significant effect on the blood profile.

The result in this study also presented that concentration of $\mathrm{Hb}, \mathrm{PCV}, \mathrm{RBC}$, and $\mathrm{WBC}$ were increased significantly with dietary of combination fresh duckweed and dried duckweed (F3 and F4). These results indicated that the interaction of chemical compounds in duckweed with the molecule in cells increased effect on the erythropoiesis by specific signaling factors. Mushawwir et 
al. (2010) and Slimen et al. (2016) suggested that all blood cells form from a single type of stem cell, through a process called hematopoiesis. The specific signaling is one main factor to support this process in the hematopoietic organs. Cheng et al. (2014) reported specific signaling factors were involved in triggering the production of different types of blood cells. Erythropoietin is a hormone released from the kidney and triggers the differentiation of stem cells into erythrocytes. Although, previous study demonstrated the heterogeneous results in the effect natural extract on hematological profile, the simultaneous effect with duckweed in this experiment leads to a growth blood cell formation of the dairy cow.

Previous studies have been widely reported on the mechanism and role of natural extracts on the formation of blood cells and the immune system in ruminants. Collier et al. (2012) and Allen et al. (2015) reported that giving phenol from duckweed extract was able to increase the activity of enzymes that catalyze blood formation and improve the $\mathrm{L} / \mathrm{N}$ ratio, thereby reducing the risk of stress in ruminant. The other report showed that the phenol can reduce free radical activities in commercial poultry (Anderson et al. 2013; Adriani et al. 2015; Kamil et al. 2020; Adriani and Mushawwir 2020), and increasing for antioxidant activities in pet animal (McManaman et al. 2017; Mushawwir et al. 2018). The other investigators have shown an increase in oxygen flow in the blood as a result of the addition of duckweed in rabbit rations (Roland et al. 2016). The results of this previous study, reinforce the fact that duckweed contributes to $\mathrm{Hb}$ resistance in red blood cells.

\section{Antioxidants status}

The effects of duckweed supplementation with different levels of antioxidants profiles of dairy cows are shown in Table 2. Diet supplemented with duckweed, individually or combination of concentrate with duckweed had a significant effect $(\mathrm{P}<0.05)$ on all of the antioxidant parameters.

The potential of duckweed as an ingredient that contains antioxidant activity, has been reported by several researchers. According to Cheng et al. (2014), the relationship between total phenol and antioxidant activity was that the lower the IC50 value, the higher the total phenol content, so that the antioxidant activity is directly proportional to the total phenol, the higher the phenol content in an the higher the activity as an antioxidant. The ethanol extract of $70 \%$ duckweed leaves has a high total phenol content because of the potential of phenolic compounds as antioxidants due to the presence of hydroxyl groups in phenol compounds. The high concentration of phenolic compounds causes the formation of phenolic ions to increase (Damaziak et al. 2017). The n-hexane and ethyl acetate extracts have a low total phenol content. According to research conducted by Soisuwan and Chauychuwong (2013), this difference in value is influenced by the level of the polarity of the solvent used in the metabolite compounds found in the sample. If the content of phenolic compounds in the sample is high, the antioxidant activity will be high. It is suspected that with an increase in total phenol, antioxidant activity is higher and greater than low phenol levels.

Table 1. The effect of duckweed levels on the hematological parameters in dairy cow

\begin{tabular}{|c|c|c|c|c|c|c|c|c|}
\hline Ration & 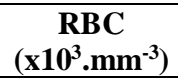 & $\begin{array}{l}\text { Hb } \\
(\mathrm{g} \%)\end{array}$ & $\begin{array}{r}\text { PCV } \\
(\%) \\
\end{array}$ & $\begin{array}{l}\text { WBC } \\
\left(\mathbf{x}^{10} 0^{3} \cdot \mathrm{mm}^{-3}\right)\end{array}$ & 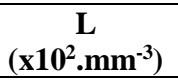 & $\begin{array}{c}\mathrm{N} \\
\left(\mathbf{x} 10^{2} \cdot \mathrm{mm}^{-3}\right)\end{array}$ & $\begin{array}{l}\text { N/L } \\
\text { Ratio }\end{array}$ & $\begin{array}{c}\mathbf{E S R} \\
\left(\mathbf{m L} \cdot \mathbf{h}^{-1}\right)\end{array}$ \\
\hline F0 & $4.78 \pm 0,15^{\mathrm{a}}$ & $9.5 \pm 0.41^{\mathrm{a}}$ & $3.87 \pm 0.132^{\mathrm{a}}$ & $66.21 \pm 0.32^{\mathrm{a}}$ & $5.28 \pm 0.16^{\mathrm{a}}$ & $21.045 \pm 0.58^{\mathrm{a}}$ & $3.98 \pm 0,11^{\mathrm{a}}$ & $5.13 \pm 0.33^{\mathrm{a}}$ \\
\hline $\mathrm{F} 1$ & $4.12 \pm 0,11^{\mathrm{b}}$ & $12.5 \pm 0.31^{\mathrm{b}}$ & $37.38 \pm 0.16^{\mathrm{b}}$ & $92.26 \pm 0.13^{b}$ & $5,78 \pm 0.24^{\mathrm{a}}$ & $18.37 \pm 0.32^{\mathrm{b}}$ & $3.21 \pm 0.13^{\mathrm{a}}$ & $3.82 \pm 0.53^{b}$ \\
\hline $\mathrm{F} 2$ & $5.14 \pm 0,13^{b}$ & $12.4 \pm 0.45^{\mathrm{b}}$ & $35.63 \pm 0.14^{\mathrm{b}}$ & $93.89 \pm 0.14^{\mathrm{c}}$ & $6.67 \pm 0.28^{b}$ & $18,27 \pm 0.21^{\mathrm{b}}$ & $2.73 \pm 0.28^{b}$ & $3.74 \pm 0.34^{b}$ \\
\hline F3 & $5.12 \pm 0,08^{b}$ & $12.3 \pm 0.54^{\mathrm{b}}$ & $38.47 \pm 0.13^{b}$ & $92.13 \pm 0.03^{\mathrm{b}}$ & $6.79 \pm 0.18^{b}$ & $18,52 \pm 0.31^{b}$ & $2.72 \pm 0.31^{\mathrm{b}}$ & $3.81 \pm 0.72^{b}$ \\
\hline F4 & $5.24 \pm 0,04^{\mathrm{c}}$ & $12.8 \pm 0.55^{\mathrm{b}}$ & $37.46 \pm 0.22^{\mathrm{b}}$ & $93.13 \pm 0.32^{\mathrm{c}}$ & $7.67 \pm 0.17^{b}$ & $18.56 \pm 0.17^{\mathrm{b}}$ & $2.43 \pm 0.16^{\mathrm{bc}}$ & $3.83 \pm 0.34^{\mathrm{b}}$ \\
\hline
\end{tabular}

Note: RBC: Red blood cells; Hb: Hemoglobin; PCV: packed cell volume; WBC: White blood cells; L: Lymphocytes; N: Neutrophil ESR: erythrocyte sedimentation rate. ${ }^{a, b, c}$ Means in each column with different superscripts are significantly different $(p<0.05)$, Value are given in Means \pm SD

Table 2. The effect of duckweed levels on some parameters related antioxidant of blood plasma in dairy cow

\begin{tabular}{|c|c|c|c|c|c|}
\hline \multirow{2}{*}{ Parameters } & \multicolumn{5}{|c|}{ Ration } \\
\hline & F0 & F1 & F2 & F3 & F4 \\
\hline Glutathione peroxidase, $\mathrm{nmol} \mathrm{mg}^{-1}$ & $4.52 \pm 0.47^{\mathrm{a}}$ & $5.67 \pm 3.72^{\mathrm{b}}$ & $7.48 \pm 4.72^{\mathrm{b}}$ & $8.73 \pm 4.25^{\mathrm{b}}$ & $8.76 \pm 1.47^{b}$ \\
\hline Glutathione reductase, $\mathrm{nmol}^{\mathrm{mg}}{ }^{-1}$ & $2.62 \pm 0.03^{\mathrm{a}}$ & $6.65 \pm 5.07^{\mathrm{b}}$ & $8.73 \pm 4.01^{\mathrm{b}}$ & $9.53 \pm 3.06^{c}$ & $9.53 \pm 2.24^{\mathrm{c}}$ \\
\hline Superoxide dismutase, nmol.mg ${ }^{-1}$ & $2.01 \pm 0.26^{\mathrm{a}}$ & $3.93 \pm 1.05^{\mathrm{b}}$ & $3.84 \pm 1.92^{\mathrm{c}}$ & $3.93 \pm 1.02^{\mathrm{b}}$ & $3.91 \pm 1.11^{\mathrm{b}}$ \\
\hline Soluble transferrin receptor, mg.dl- ${ }^{-1}$ & $0.95 \pm 0.01^{\mathrm{a}}$ & $1.74 \pm 1.58^{\mathrm{b}}$ & $0.69 \pm 1.74^{\mathrm{a}}$ & $2.83 \pm 0.28^{c}$ & $2.73 \pm 1.75^{\mathrm{c}}$ \\
\hline Total iron binding capacity, mg.dl ${ }^{-1}$ & $2.36 \pm 0.23^{\mathrm{a}}$ & $2.62 \pm 3.56^{\mathrm{a}}$ & $3.04 \pm 3.52^{\mathrm{b}}$ & $2.39 \pm 4.19^{\mathrm{b}}$ & $2.17 \pm 3.58^{\mathrm{b}}$ \\
\hline Transferrin $\left(\mathrm{mg}^{\left.-\mathrm{dl}^{-1}\right)}\right.$, & $1.22 \pm 0.11^{\mathrm{a}}$ & $2.79 \pm 0.71^{\mathrm{b}}$ & $2.97 \pm 0.27^{\mathrm{b}}$ & $3.98 \pm 0.53^{c}$ & $4.49 \pm 0.43^{\mathrm{d}}$ \\
\hline Ferritin, nmol.mg ${ }^{-1}$ & $0.93 \pm 0.03^{\mathrm{a}}$ & $0.53 \pm 0.02^{\mathrm{b}}$ & $0.51 \pm 0.01^{\mathrm{b}}$ & $0.38 \pm 0.02^{c}$ & $0.39 \pm 0.01^{\mathrm{c}}$ \\
\hline Ceruloplasmin, mg.dl ${ }^{-1}$ & $1.32 \pm 0.16^{\mathrm{a}}$ & $1.35 \pm 0.35^{\mathrm{b}}$ & $1.46 \pm 0.18^{\mathrm{b}}$ & $1.26 \pm 0.15^{\mathrm{b}}$ & $1.35 \pm 0.28^{\mathrm{b}}$ \\
\hline Albumin, mg.dl ${ }^{-1}$ & $1.78 \pm 1.13^{\mathrm{a}}$ & $2.31 \pm 1.24^{\mathrm{a}}$ & $3.06 \pm 0.14^{\mathrm{b}}$ & $3.14 \pm 1.17^{\mathrm{b}}$ & $3.07 \pm 0.13^{\mathrm{b}}$ \\
\hline Bilirubin total, mg.dl ${ }^{-1}$ & $1.21 \pm 0.02^{\mathrm{a}}$ & $1.23 \pm 0.05^{\mathrm{a}}$ & $1.13 \pm 0.11^{\mathrm{a}}$ & $2.15 \pm 0.08^{\mathrm{b}}$ & $2.24 \pm 0.02^{\mathrm{b}}$ \\
\hline Bilirubin direct, mg. $\mathrm{dl}^{-1}$ & $2.43 \pm 0.12^{\mathrm{a}}$ & $3.54 \pm 1.08^{\mathrm{a}}$ & $4.19 \pm 1.09^{\mathrm{a}}$ & $5.29 \pm 0.10^{\mathrm{b}}$ & $5.31 \pm 0.11^{\mathrm{b}}$ \\
\hline Uric acid, mg.dl ${ }^{-1}$ & $8.52 \pm 1,64^{\mathrm{a}}$ & $8.69 \pm 0,23$ & $7.85 \pm 0,24^{b}$ & $7.72 \pm 0.32^{\mathrm{b}}$ & $7.60 \pm 0.74^{b}$ \\
\hline Total antioxidant status, $\mathrm{nmol}^{-\mathrm{mg}^{-1}}$ & $9.96+0.42^{\mathrm{a}}$ & $11.35 \pm 0.01^{\mathrm{b}}$ & $11.36 \pm 0.01^{\mathrm{b}}$ & $11.32+0.02^{\mathrm{b}}$ & $13.31+0.02^{\mathrm{c}}$ \\
\hline
\end{tabular}


Duckweed is often used as a traditional medicine because it has a variety of benefits such as: anticancer, antidiabetic (Korivi et al. 2012), antifungal (Vizzotto et al. 2015), antimicrobial (Pickler et al. 2013; Tian et al. 2015), anti-inflammatory and analgesic (Xu et al. 2015; Moreno et al. 2015; Kusmayadi et al. 2018), antioxidant (Mushawwir et al. 2010, 2011; Hecker and McGarvey 2011; Fabris et al. 2017), and sedative activity from the nervous system (Azis et al. 2012; De Castro et al. 2013; Pouyssegur and MechtaGrigoriou 2016). These activities can be produced because of the role of chemical compounds contained therein such as alkaloids, phenols, flavonoids (He et al. 2009) and the other report showed some chemicals such as tannins, anthocyanins, glycosides, bufadienolides, saponins, coumarin, sitosterol, quinine, and lectins (O'Brien et al. 2010; Rhoads et al. 2013; Shehab-El-Deen et al. 2014). Several other researchers report, this plant is rich in phenolic compounds, especially quercetin as the major flavonoid of this species.

The biological effects of duckweed on blood synthesis appear to be influenced by their glycoside content. Anonymously (48484) shows the role of glycosides in increasing the rate of erythropoiesis. Increased lymphocyte production and decreased neutrophil production in this study (Table 1) by administering F2-F2 ration, confirmed that duckweed was able to increase the growth of B and T lymphocyte cells (Holt et al. 2010). The growth and performance of these two cells is the role of duckweed which has the ability to prevent inflammation by flavonoids and tannins.

Based on the results of this study it can be stated that duckweed can play a role in avoiding radical compounds thereby reducing the impact of lipid peroxidation by radical compounds. This decrease in lipid peroxidation is shown by the increased ability of Iron blood cells to transport oxygen, as well as an increase in transferrin receptors and transferrin levels in blood plasma. The results of previous studies show the same indications with the results of this study. Mushawwir et al. (2018) have shown the effect of some natural extracts to an increase in oxygen consumption as an effect of increasing levels of transferrin in poultry. Zahner et al. (2014) also reported improvements in metabolic rate and the other investigator showed an increase level of antioxidants in small ruminants, and in beef cattle (Mushawwir et al. 2010,2011; Roland et al. 2016), and dairy cows and rats (Arya et al. 2014; Monteiro et al. 2016; Nguyen et al. 2016). The results of research by Hidayat et al. (2011) showed that feeding natural extracts increased the digestibility and absorption of nutrients in the rumen. Phenols contained in natural ingredients seem to be able to stimulate specific protein synthesis in the liver cells (Gray et al. 2015; Adriani and Mushawwir 2020; Kamil et al. 2020).

Based on the results of this investigation, combining duckweed with concentrated resulted in supplemented levels that significantly enhanced the hematological and antioxidants profile, therefore, we conclude that duckweed (fresh or dried) can be used to improve performance in dairy cow.

\section{ACKNOWLEDGEMENTS}

The authors are grateful to the Laboratory of Animal Physiology and Biochemistry, Animal Science Faculty Universitas Padjadjaran and Directorate General of Higher Education, Ministry of Research, Technology, and High Education of Indonesia for their financially supported in this experiment. Much appreciation goes Aziz (Quartilab) for their assistance with some equipment, calibrations, and conduct of these experiments, and Adang Sudrajat (FTB Fapet Unpad, Indonesia) for his assistance in handling animal samples.

\section{REFERENCES}

Adriani L, Abun, Mushawwir A. 2015. Effect of dietary supplementation of Jengkol (Pithecellobium jiringa) skin extract on blood biochemistry and gut flora of broiler chicken. Intl J Poult Sci 14: 407410.

Adriani L, Mushawwir A. 2020. Correlation between blood parameters, physiological and liver gene expression levels in native laying hens under heat stress. IOP Conf Ser Earth Environ Sci 466: 012015. DOI: 10.1088/1755-1315/466/1/012015.

Allen JD, Hall LW, Collier RJ, Smith JF. 2015. Effect of core body temperature, time of day, and climate conditions on behavioral patterns of lactating dairy cows experiencing mild to moderate heat stress. J Dairy Sci 98: 118-127.

Anderson SD, Bradford BJ, Harner JP. 2013. Effects of adjustable and stationary fans with misters on core body temperature and lying behavior of lactating dairy cows in a semiarid climate. J Dairy Sci 96: 4738-4750.

Arya A, Al-Obaidi MM, Shahid N, Bin Noordin MI, Looi CY, Wong WF, Khaing SL, Mustafa MR. 2014. Synergistic effect of quercetin and quinic acid by alleviating structural degeneration in the liver, kidney and pancreas tissues of STZ-induced diabetic rats: a mechanistic study. Food Chem Toxicol 71: 183-196.

Azis A, Abbas H, Heryandi Y, Kusnadi E. 2012. Thyroid hormone and blood metabolites concentrations of broiler chickens subjected to feeding time restriction. Media Peternakan 35: 32-37.

Cheng JB, Wang WY, Zheng N. 2014. Natural period change of heat stress reveals unique "heat-stressed milk protein decrease syndrome" in mid-lactation dairy cows. China Anim Husbandry Vet Med 41:7384.

Collier RJ, Hall LW, Rungruang S, Zimbleman RB. 2012. Quantifying heat stress and its impact on metabolism and performance. Ann Ruminant Nutr Symp 12: 74-83.

Damaziak K, Riedel J, Gozdowski D, Niemiec J, Siennicka A, Róg D. 2017. Productive performance and egg quality of laying hens fed diets supplemented with garlic and onion extracts. J Appl Poult Res 26: 337-349.

De Castro NM, Yaqoob P, de la Fuente M, Baeza I, Claus SP. 2013. Premature impairment of methylation pathway and cardiac metabolic dysfunction in fa/fa obese Zucker rats. J Proteome Res 12: 19351945.

Fabris TF, Laporta J, Corra FN. 2017. Effect of nutritional immunomodulation and heat stress during the dry period on subsequent performance of cows. J Dairy Sci 100: 6733-6742.

Geburt K, Friedrich M, Piechotta M, Gauly M, Koning von BU. 2015. Validity of physiological biomarkers for maternal behavior in cows: A comparison of beef and dairy cattle. Physiol Behav 139: 361-368.

Gray LR, Sultana MR, Rauckhorst AJ. 2015. Hepatic mitochondrial pyruvate carrier 1 is required for efficient regulation of gluconeogenesis and whole-body glucose homeostasis. Cell Metab 22: 669-681.

He ML, Yang WZ, You JS, Chaves AV, Mir PS, Benchaar C, McAllister TA. 2009. Effects of garlic oil on fatty acid accumulation and glycerol-3-phosphate dehydrogenase activity in differentiating adipocytes. J Anim Sci 22: 1686-1692. 
Hecker JG, McGarvey M. 2011. Heat shock proteins as biomarkers for the rapid detection of brain and spinal cord ischemia: a review and comparison to other methods of detection in thoracic aneurysm repair. Cell Stress Chaperones 16: 119-131.

Holt PS, Vaughn LE, Gast RK. 2010. Flow cytometric characterization of Peyer's patch and cecal tonsil $\mathrm{T}$ lymphocytes in laying hens following challenge with Salmonella enterica serovar enteritidis. Vet Immunol Immunopathol 133: 276-281.

Ippolito DL, Lewis JA, Yu C, Leon LR, Stallings JD. 2014. Alteration in circulating metabolites during and after heat stress in the conscious rat: potential biomarkers of exposure and organ-specific injury. BMC Physiol 14: 14. DOI: 10.1186/s12899-014-0014-0.

Kamil KA, Latipudin D, Mushawwir A, Rahmat S, Balia RL. 2020. The Effects of ginger volatile oil (GVO) on the metabolic profile of glycolytic pathway, free radical and antioxidant activities of heatstressed cihateup duck. Intl J Adv Sci Eng Inf Technol 10: 12281233.

Korivi M, Hou CW, Huang CY, Lee SD, Hsu MF, Yu SH, Chen CY, Liu YY, Kuo CH. 2012. Ginsenoside-rg1 protects the liver against exhaustive exercise induced oxidative stress in rats. Evid Based Compl Altern Med 20: 932-941.

Kusmayadi A, Adriani L, Abun, Muhctaridi, Tanuwiria UH. 2018. The effect of solvents and extraction time on total xanthone and antioxidant yields of Mangosteen peel (Garcinia mangostana L.) extract. Drug Invent. Today 10: 2572-2576.

Lai YS, Chen WC, Ho CT, Lu KH, Lin SH, Tseng HS, Lin SY, Sheen LY. 2016. Garlic essential oil protects against obesity-triggered nonalcoholic fatty liver disease through modulation of lipid metabolism and oxidative stress. J Agric Food Chem 62: 5897-906.

Leroy JL, Vanholder T, Van Knegsel AT, Garcia-Ispierto I, Bols PE. 2008. Nutrient prioritization in dairy cows early postpartum: mismatch between metabolism and fertility. Reprod Domest Anim 43: 96-103.

McManaman JL, Bales ES, Orlicky DJ, Jackman M, MacLean PS, Cain S, Crunk AE, Mansur A, Graham CE, Bowman TA, Greenberg AS 2017. Perilipin-2-null mice are protected against diet-induced obesity, adipose inflammation, and fatty liver disease. J Lipid Res 54: 13461359.

Monteiro AP, Guo JR, Weng XS. 2016. Effect of maternal heat stress during the dry period on growth and metabolism of calves. J Dairy Sci 99: 3896-3907.

Moreno KX, Moore CL, Burgess SC. 2015. Production of hyperpolarized $13 \mathrm{CO} 2$ from [1-13C] pyruvate in perfused liver does reflect total anaplerosis but is not a reliable biomarker of glucose production. Metabolomics 11: 1144-1156.

Mushawwir A, Adriani L, Kamil KA. 2011. Prediction models for olfactory metabolic and sows\% rnareticulocyt (rnart) by measurement of atmospheric ammonia exposure and microclimate level. J Indon Trop Anim Agric 36: 14-20.

Mushawwir A, Tanuwiria UH, Kamil KA, Adriani L, Wiradimadja R, Suwarno N. 2018. Evaluation of haematological responses and blood biochemical parameters of heat-stressed broilers with dietary supplementation of Javanese ginger powder (Curcuma xanthorrhiza) and Garlic extract (Allium sativum). Intl J Poult Sci 17: 452-458.

Mushawwir A, Yong YK, Adriani L, Hernawan E, Kamil KA. 2010. The fluctuation effect of atmospheric ammonia (nh3) exposure and microclimate on Hereford bulls hematochemical. J Indon Trop Anim Agric 35: 232-238.

Nguyen TT, Bowman PJ, Haile-Mariam M, Pryce JE, Hayes BJ. 2016. Genomic selection for tolerance to heat stress in Australian dairy cattle. J Dairy Sci 99: 2849-62.
O'Brien MD, Rhoads RP, Sanders SR, Duff GC, Baumgard LH. 2010. Metabolic adaptations to heat stress in growing cattle. Domest Anim Endocrinol 38: 86-94

Odore R, Badino P, Re G, Barbero R, Cuniberti B, D’Angelo A, Girardi C, Fraccaro E, Tarantola M. 2011. Effects of housing and short-term transportation on hormone and lymphocyte receptor concentrations in beef cattle. Res Vet Sci 90: 341-345.

Pearce SC, Gabler NK, Ross JW, Escobar J, Patience JF, Rhoads RP, Baumgard LH. 2013. The effect of heat stress and plane of nutrition on metabolism in growing pigs. J Anim Sci 91: 2108-2118.

Pickler L, Breno C B, Beirão, Ricardo M, Hayashi, Jean FD, Mariana CL, Luiz FC, Santin E. 2013. Effect of sanguinarine in drinking water on Salmonella control and the expression of immune cells in peripheral blood and intestinal mucosa of broilers. J Appl Poult Res 22: 430438.

Pouyssegur J, Mechta-Grigoriou F. 2016. Redox regulation of the hypoxia-inducible factor. Biol Chem 387: 1337-1346.

Rhoads RP, Baumgard LH, Suagee JK. 2013. Metabolic priorities during heat stress with an emphasis on skeletal muscle. J Anim Sci 91: 24922503.

Roland L, Drillich M, Klein-Jobstl D, Iwernes M. 2016. Invited review: Influence of climatic conditions on the development, performance, and health of claves. J Dairy Sci 99: 2438-2452.

SAS Institute. 2011. Statistical analysis for Biological Science. SAS Institute Inc., Germany.

Sasmaz M, Emine IAT, Erdal O, Ahmet S. 2015. The potential of Lemna gibba L. and Lemna minor $\mathrm{L}$. to remove $\mathrm{Cu}, \mathrm{Pb}, \mathrm{Zn}$, and As in gallery water in a mining area in Keban, Turkey. J Environ Manag 163: 246253.

Saygideger S, Gulnaz O, Erman SI, Nebil Y. 2015. Adsorption of Cd (II), $\mathrm{Cu}$ (II) and $\mathrm{Ni}$ (II) ions by Lemna minor L.: Effect of physicochemical environment. J Hazard Mater B126: 96-104.

Shehab-El-Deen MAMM, Fadel MS, Van Soom A. 2014. Circadian rhythm of metabolic changes associated with summer heat stress in high-producing dairy cattle. Trop Anim Health Prod 42: 1119-1125.

Siskos AP, Jain P, Romisch-Margl W. 2017. Interlaboratory reproducibility of a targeted metabolomics platform for analysis of human serum and plasma. Anal Chem 89: 656-665.

Slimen B, Najar T, Ghram A, Abdrranna M. 2016. Heat stress effects on livestock: molecular, cellular and metabolic aspects, a review. J Anim Physiol Anim Nutr (Berl) 100: 401-412.

Soisuwan K, Chauychuwong C. 2013. Effects of phytogenic feed additive with reduced dietary metabolizable energy and digestible essential amino acids on carcass yields and meat quality of Pekin ducks. Appl Sci 9: 6099-6102.

Tanuwiria UH, Santosa U, Yulianti AA, Suryadi U. 2011. The Effect of organic-Cr dietary supplementation on stress response in transportstressed beef cattle. J Indon Trop Anim Agric 36: 97-103.

Tian H, Wang W, Zheng N. 2015. Identification of diagnostic biomarkers and metabolic pathway shifts of heat-stressed lactating dairy cows. J Proteomics 125:17-28.

Vizzotto EF, Fischer V, Thaler NA. 2015. Access to shade changes behavioral and physiological attributes of dairy cows during the hot season in the subtropics. Animal 9: 1559-1566.

Xu B, Chen M, Ji X. 2015. Metabolomic profiles reveal key metabolic changes in heat stress-treated mouse Sertoli cells. Toxicol In Vitro 29: 1745-52.

Zahner M, Schrader L, Hauser R. 2014. The influence of climatic conditions on physiological and behavioural parameters in dairy cows kept in open stables. Anim Sci 78: 139-148 